\title{
Immobilization of Enzymes in Protein Films Prepared Using Transglutaminase
}

\author{
Masao Motoki, Hiroshi Aso, Katsuya Seguro \\ and Noriki Nio \\ Central Research Laboratories, Ajinomoto Co., Inc., \\ 1-1, Suzuki-cho, Kawasaki-ku, Kawasaki 210, Japan
}

Received August 27, 1986

\begin{abstract}
An $\alpha_{\mathrm{s} 1}$-casein film prepared using transglutaminase was applied as a support for immobilized enzymes. That is, the enzyme to be immobilized was added to a mixture of $5 \% \alpha_{\mathrm{s} 1}$-casein and transglutaminase. Before gelation by means of the transglutaminase-reaction, the reaction mixture was quickly spread on a horizontal plate. The immobilized enzyme film was removed from the plate after air-drying. Attempts were made to immobilize several enzymes, such as $\beta$-glucosidase, $\alpha$ mannosidase, $\beta$-galactosidase and glucose oxidase. None of the immobilized enzymes lost activity on repeated usage. The enzymes tested were evidently immobilized through entrapment in the lattice of the protein film. Some enzymic characteristics of the immobilized enzymes showed that this new technique was as good as other known immobilization methods.
\end{abstract}

As supports for enzymes immobilized by the entrapment method, many materials such as synthetic polymers and natural polymers have been studied. ${ }^{1)}$ These materials are generally insolubilized with an enzyme by means of chemical reaction, irradiation and/or heat treatment. The selection of natural polymers as enzyme-supporting materials is thought to be advantageous for food use. However, the practical use of natural polymers, such as collagen, agar-agar, alginic acid, etc., imvolves many problems. For example, the immobilized enzymes are liable to leak with an alteration in temperature, $\mathrm{pH}$, etc. Therefore, it was necessary. to develop a new and more effective immobilization technique.

Recently, we succeeded in preparing a protein film using transglutaminase (EC 2.3.2.13, TGase). ${ }^{2)}$ TGase is an enzyme which catalyzes the formation of intra- and/or intermolecular $\varepsilon$-( $\gamma$-glutamyl)lysyl cross-links between protein molecules. ${ }^{3)}$ Several proteins $\left(\alpha_{\mathrm{s} 1}\right.$-casein, soybean globulins, etc.) were found to be gelled by TGase under high substrate concentration conditions. ${ }^{4)}$ 'Therefore, this gelation mechanism was applied to the immobilization of enzymes. When a protein film is to be used as a support for immobilized enzymes, the following merits are expected. Firstly, the gelation with TGase is possible under such mild conditions that it is excellent for the immobilization of heat-labile enzymes. Secondly, as the supporting material is made of a food protien, i.e., bovine casein, it may be more applicable to the production of food materials. In practice, the enzymes were successfully immobilized by spreading a mixture of the substrate protein, TGase and the target enzyme on the plate before gelation by TGase.

In this paper, we describe the preparation and some characteristics of the immobilized enzymes with the protein film formed by TGase as their supports.

\section{MATERIALS AND METHODS}

Transglutaminase and other materials. TGase was prepared from fresh guinea pig liver according to the method of Connellan et al. ${ }^{5)}$ The specific activity and other characteristics were the same as those given in a previous paper ${ }^{6)} \alpha_{\mathrm{s} 1}$-Casein was prepared from fresh cow's milk by Zittle and Custer's method. ${ }^{7)} \beta$-Glucosidase, $\alpha$-mannosidase, $\beta$-galactosidase and glucose oxidase were ob- 
tained from Sigma Chemical Co. Peroxidase, 3-methyl2-benzothiazolinone-hydrazone and diethylaniline were purchased from Wako Pure Chemical Industries Ltd. $p$-Nitrophenyl- $\beta$-D-glucopyranoside, $\quad p$-nitrophenyl- $\alpha$-Dmannopyranoside and $p$-nitrophenyl- $\beta$-D-galactopyranoside were obtained from Nakarai Chemical Ltd.

Preparation of immobilized enzymes. Fifty milligrams of $\alpha_{\mathrm{s} 1}$-casein was dissolved in $0.8 \mathrm{ml}$ of $0.1 \mathrm{M}$ Tris- $\mathrm{HCl}$ buffer (pH 7.6) containing $5 \mathrm{~mm} \mathrm{CaCl}_{2}$ and $10 \mathrm{~mm}$ dithiothreitol. One hundred microliters of each enzyme solution $(10 \mathrm{mg} / \mathrm{ml}), 0.05 \mathrm{ml}$ of TGase (120 units $/ \mathrm{ml})$ and $0.01 \mathrm{ml}$ of $2.0 \%$ glycerol were added to this solution, which was then immediately spread on a horizontal polymethacrylate board $(20 \times 50 \mathrm{~mm})$ with a frame (depth, $1.5 \mathrm{~mm})$. After air-drying at $40^{\circ} \mathrm{C}$ for $5 \mathrm{hr}$, the immobilized enzyme film formed was removed from the board and stored at $4^{\circ} \mathrm{C}$. The films obtained had water concentrations of $11 \pm 2 \%$ and were of $45 \pm 5 \mu \mathrm{m}$ thickness. It was confirmed that the TGase in the $\alpha_{\mathrm{s} 1}$-casein films was inactivated.

\section{Measurement of each enzyme activities}

1) $\beta$-Glucosidase. One milliliter of $2.0 \mathrm{~m} p$-nitrophenyl$\beta$-D-glucopyranoside in $0.05 \mathrm{M}$ sodium citrate buffer $(\mathrm{pH}$ 5.0) was incubated with $\beta$-glucosidase for $10 \mathrm{~min}$ at $25^{\circ} \mathrm{C}$. The reaction was quenched by adding $3.0 \mathrm{ml}$ of $0.2 \mathrm{M}$ sodium borate $(\mathrm{pH} 9.8)$, and then the amount of $p$ nitrophenol formed was measured at $400 \mathrm{~nm} .^{8}$ One unit of the enzyme activity was defined as the amount of the enzyme which hydrolyzed $1 \mu \mathrm{mol}$ of $p$-nitrophenyl- $\beta$-Dglucopyranoside per minute.

2) $\alpha$-Mannosidase and $\beta$-galactosidase. The measurements of these enzyme activities were performed in the same manner as for in the case of $\beta$-glucosidase. In the case of $\alpha$-mannosidase, $p$-nitrophenyl- $\alpha$-D-mannopyranoside was used as the substrate and the $\mathrm{pH}$ of the solution was 4.5 . In the case of $\beta$-galactosidase, $p$-nitrophenyl- $\beta$-D-galactopyranoside was used as the substrate and the $\mathrm{pH}$ of the solution was 3.5 .

3) Glucose oxidase. One milligram of 3-methyl-2benzothiazolinone-hydrazone (MBTH), $0.4 \mathrm{ml}$ of diethylaniline (DEA) and $100 \mathrm{mg}$ of EDTA $\cdot 2 \mathrm{Na}$ were dissolved in 1.0 liter of water (MBTH-DEA solution). Peroxidase was dissolved in $0.1 \mathrm{M}$ sodium acetate to give a concentration of 8 purpurogallin units/ml (POD solution). A mixture of $2.0 \mathrm{ml}$ of the MBTH-DEA solution and $0.5 \mathrm{ml}$ of the POD solution was preincubated with glucose oxidase for $5 \mathrm{~min}$ at $37^{\circ} \mathrm{C}$. Fifteen percent glucose in $0.1 \mathrm{M}$ acetic acid was added to the preincubated solution, and then the reaction was allowed to proceed for $15 \mathrm{~min}$ at $37^{\circ} \mathrm{C}$. The reaction was quenched by adding $1.0 \mathrm{ml}$ of $0.5 \mathrm{~N} \mathrm{HCl}$. The amount of indamine dye formed during the reaction was measured at $590 \mathrm{~nm} .{ }^{9)}$ One unit of enzyme activity was defined as the amount of enzyme which oxidized $1 \mu \mathrm{mol}$ of glucose per minute.
Activity yields of the immobilized enzymes. The activity yields were calculated as the ratio of the determined activity of an enzyme to the activity in the same volume of the initial enzyme solution, which was expressed as:

$$
\begin{aligned}
& P \text { (as percent) } \\
& \quad=\frac{\text { overall activity of the insolubilized enzyme }}{\text { overall activity of the initial enzyme solution }} \times 100 \text {. }
\end{aligned}
$$

Test for enzyme-leakage from the support. An immobilized enzyme film was cut into small chips of $5 \times 5 \mathrm{~mm}$ on average. One chip of the film was immersed in $1.0 \mathrm{ml}$ of the buffer at the optimum $\mathrm{pH}$ and then shaken for $10 \mathrm{~min}$ at the optimum temperature. After that, a $0.1 \mathrm{ml}$ sample of the buffer solution was taken for enzyme activity measurement. The amount of leaked enzyme was expressed as the percentage per overall activity of the initial film chip.

SDS-polyacrylamide gel electrophoresis (SDS-PAGE). SDS-PAGE was carried out on a $12.5 \%$ acrylamide slab gel using the discontinuous system described by Laemmli. ${ }^{10)}$ The gel was stained with Coomassie Brilliant Blue R-250 in a mixture of methanol-acetic acid-water $(5: 2: 13, v / v / v)$, and then destained in a mixture of methanol-acetic acid-water $(3: 1: 6, \mathrm{v} / \mathrm{v} / \mathrm{v})$.

\section{RESULTS}

\section{Reusability and activity yields}

The activities of $\beta$-glucosidase, $\alpha$-mannosidase, $\beta$-galactosidase and glucose oxidase were measured at 10 different times to examine their reusability. After one measurement, the film was taken out of the reaction medium and then washed with each buffer. After drying, the next measurement was carried out. The results are shown in Fig. 1. The immobilized $\alpha-$ mannosidase, $\beta$-galactosidase and glucose oxidase showed little reduction in activity over the 10 measurements, and the immobilized $\beta$ glucosidase showed almost constant values, about $9 \%$. In the case of immobilized $\beta$ galactosidase, repeated use gave higher activity yields, compared with the other enzymes.

\section{Storage stability}

The immobilized enzymes entrapped in the film retained their activities for more than a year when stored at $5^{\circ} \mathrm{C}$ under dry conditions. Even at room temperature, the films remained stable for more than a few months (data not shown). 

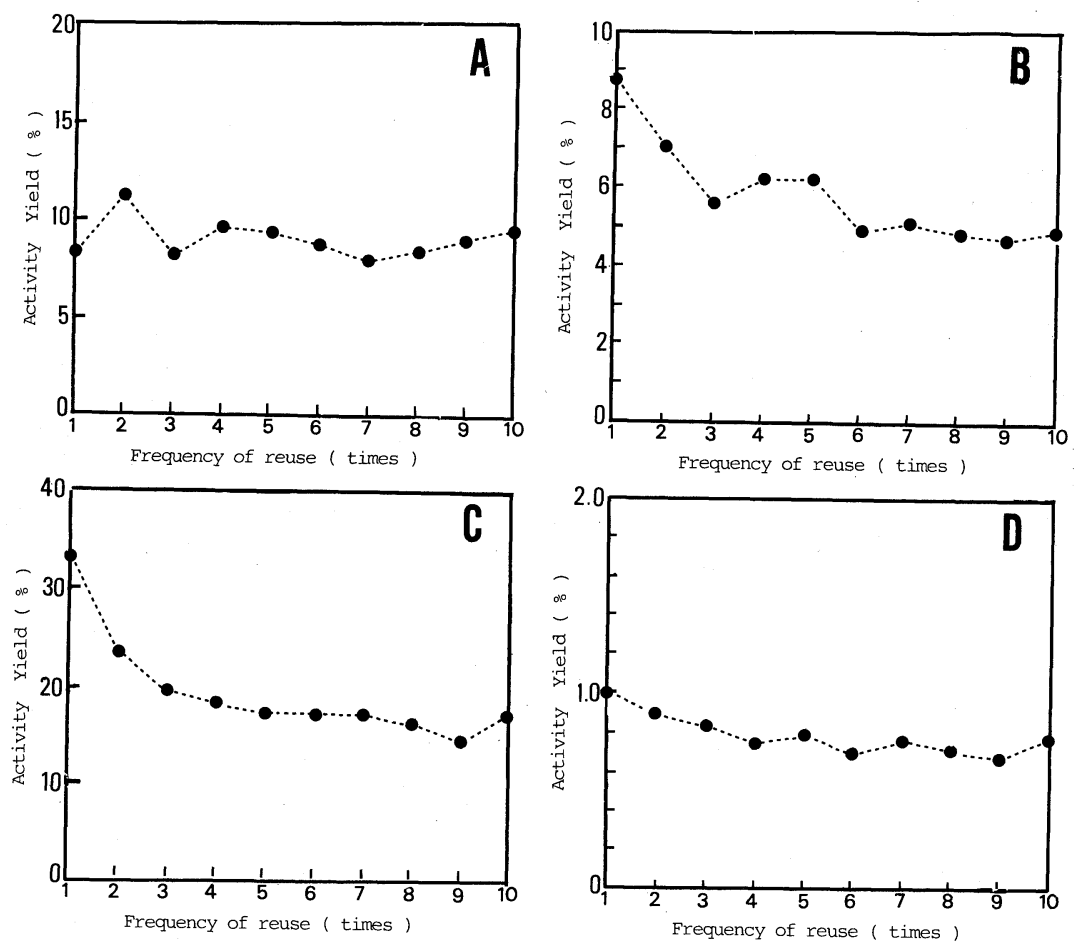

FIG. 1. The Effect of Repeated Use on the Activity Yields of the Immobilized Enzymes.

A, $\beta$-glucosidase; $\mathrm{B}, \alpha$-mannosidase; $\mathrm{C}, \beta$-galactosidase; $\mathrm{D}$, glucose oxidase.

Type of the immobilization using TGase

It was determined by SDS-PAGE whether or not each enzyme was a substrate for TGase. Figure 2 shows that glucose oxidase and $\beta$ glucosidase were scarcely polymerized by TGase. In contrast, $\alpha_{\mathrm{s} 1}$-casein was polymerized completely in two minutes. Similarly, native PAGE also indicated that the band positions of these enzymes were hardly changed by TGase (data not shown). These results show that $\alpha_{\mathrm{s} 1}$-casein is a very good substrate for the TGase-reaction, but the enzymes which were subjected to immobilization themselves were hardly affected by TGase.

\section{pH-and temperature-activity profiles}

The $\mathrm{pH}$-activity profiles are shown in Fig. 3. Relative activity was defined as the relative percentage when the highest specific activity of each enzyme was taken as $100 \%$. The profiles for $\beta$-glucosidase and $\alpha$-mannosidase shifted to the alkaline side, compared with the respective native enzymes. On the other hand, that of

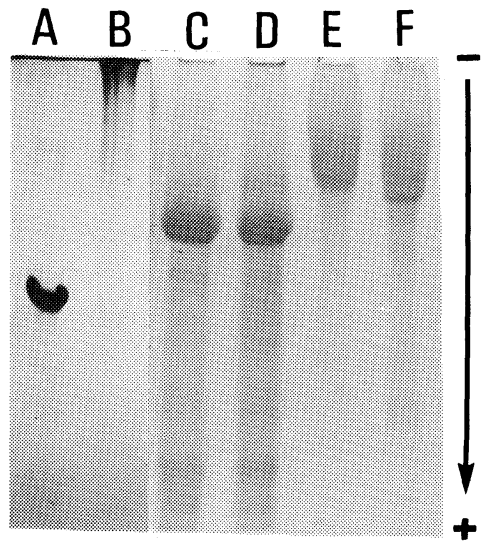

FIG. 2. SDS-Polyacrylamide Gel Electrophoresis Patterns of Native Enzymes and TGase-treated Enzymes.

A, native $\alpha_{s 1}$-casein; B, $\alpha_{s 1}$-casein treated with TGase; C, native $\beta$-glucosidase; $\mathrm{D}, \beta$-glucosidase treated with TGase; $\mathrm{E}$, native glucose oxidase; $\mathrm{F}$, glucose oxidase treated with TGase.

immobilized $\beta$-galactosidase shifted to the acidic side. In the case of glucose oxidase, a great change in the $\mathrm{pH}$-activity profile 

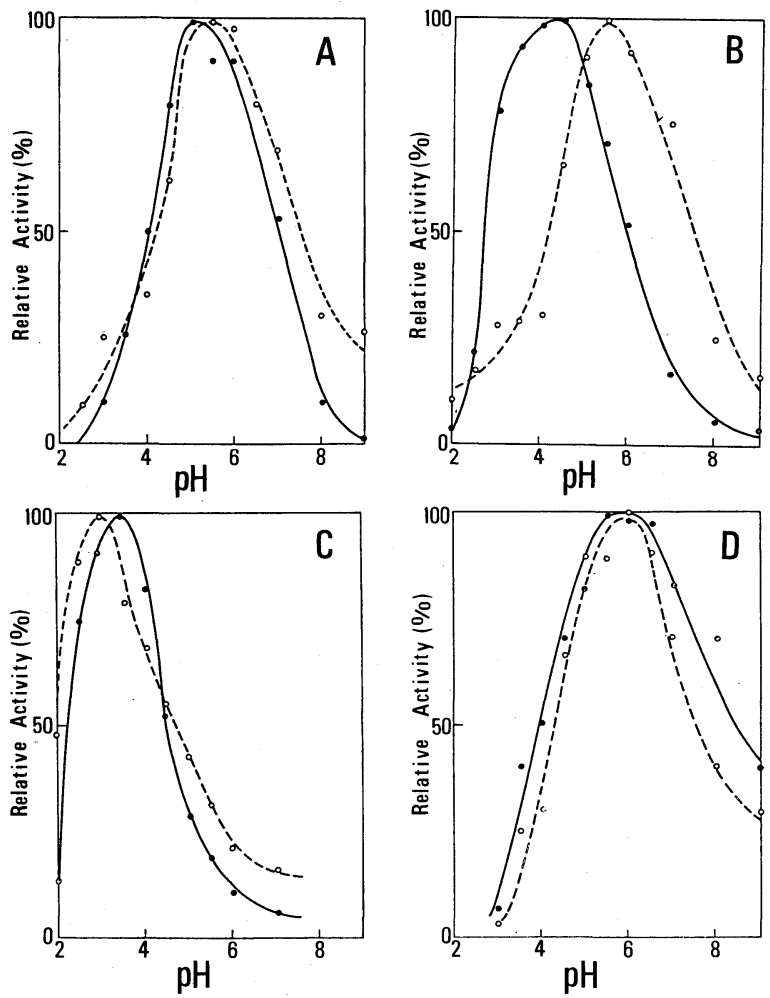

Fig. 3. pH-Activity Profiles for the Immobilized Enzymes.

$\bigcirc-\bigcirc$, immobilized enzyme; sidase; D, glucose oxidase.

was not observed during immobilization. The temperature-activity profiles are shown in Fig. 4. The relative activities of the immobilized enzymes were higher than those of the respective soluble forms around $60^{\circ} \mathrm{C}$. The above-mentioned tendency was remarkable in the case of $\beta$-glucosidase in the temperature range of $60 \sim 70^{\circ} \mathrm{C}$.

\section{Enzyme-leakage from the support}

The results of leakage tests on the immobilized enzymes are shown in Table I. Although the amount of enzyme that leaked in the case of immobilized glucose oxidase was $4.3 \%$, the other enzymes hardly leaked at all from the immobilization system.

Michaelis-Menten constants and maximal reaction velocities

Apparent kinetic parameters, i.e.,
Michaelis-Menten constants, $\mathrm{Km}$, and maximal reaction velocities, $V_{\max }$, were investigated. The results are shown in Table II. The $\mathrm{Km}$ values of all enzymes except for $\beta$-glucosidase increased on immobilization.

\section{DISCUSSION}

The protein film prepared using TGase was applied as a supporting material for some immobilized enzymes. Four enzymes, i.e., $\beta$ glucosidase, $\alpha$-mannosidase, $\beta$-galactosidase and glucose oxidase, were subjected to immobilization. As a result, all enzymes tested were successfully immobilized in the $\alpha_{s 1}$-casein film formed by TGase. It was possible to repeatedly use these immobilized enzymes. Among these enzymes, the activity yields of immobilized $\beta$ galactosidase on various supporting materials, a typical use of which has been for the hy- 

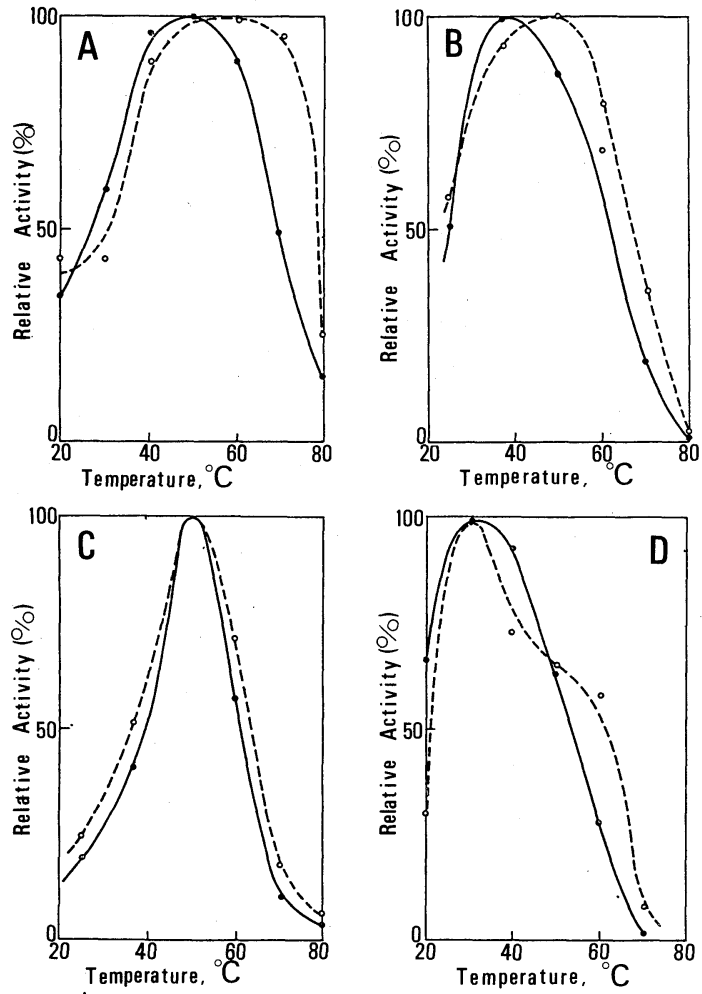

FIG. 4. Temperature-Activity Profiles for the Immobilized Enzymes.

$\bigcirc--\bigcirc$, immobilized enzyme; $\beta$-glucosidase; $\mathrm{B}, \alpha$-mannosidase; $\mathrm{C}, \beta$-galactosidase; $\mathrm{D}$, glucose oxidase.

drolysis of lactose in cow's milk, were reported to be generally in the range 10 to $50 \%{ }^{11 \sim 14)}$ Therefore, our immobilization technique, with which the activity yields ranged from 14 to $33 \%$, is nearly as good as the other known methods. We examined the possibility of the enzyme itself being cross-linked by TGase. As was expected, these enzymes were hardly cross-linked by TGase at all, only $\alpha_{\mathrm{s} 1}$-casein being easily polymerized. Thus, it was clear that the enzymes were entrapped noncovalently into the matrix of the protein film.

The $\mathrm{pH}$-activity profiles for the immobilized enzymes showed different patterns. But it is not clear why the profile for $\beta$-galactosidase was shifted to the acidic side on immobilization. The shift of the $\mathrm{pH}$-activity profiles to the alkaline side in the cases of $\alpha$-mannosidase and $\beta$-glucosidase may be closely correlated to
Table I. The Amounts of EnZymes Leaked from THE IMMOBILIZED ENZYME FILMS

\begin{tabular}{cc}
\hline Enzyme & $\begin{array}{c}\text { The amount of } \\
\text { leakage }(\%)\end{array}$ \\
\hline$\beta$-Glucosidase & 1.1 \\
$\alpha$-Mannosidase & 0.3 \\
$\beta$-Galactosidase & 0.3 \\
Glucose oxidase & 4.3 \\
\hline
\end{tabular}

TABle II. Kinetic Constants of Immobilized

Forms AND SOluble Forms OF THE ENZYMES

\begin{tabular}{llrc}
\hline Enzyme & Form & $\begin{array}{c}K m \\
(\mathrm{mM})\end{array}$ & $\begin{array}{c}V_{\max } \\
(\mu \mathrm{mol} / \mathrm{mg} / \mathrm{min})\end{array}$ \\
\hline$\beta$-Glucosidase & Soluble & 3.1 & 17.8 \\
& Immobilized & 16.7 & 2.5 \\
$\alpha$-Mannosidase & Soluble & 1.7 & 22.2 \\
& Immobilized & 3.3 & 2.5 \\
$\beta$-Galactosidase & Soluble & 1.5 & 103.1 \\
& Immobilized & 1.3 & 31.3 \\
Glucose oxidase & Soluble & 27.8 & 34.5 \\
& Immobilized & 66.7 & 0.3 \\
\hline
\end{tabular}

The enzyme activities were measured with various substrate concentrations, and the results obtained were plotted according to the method of Lineweaver and Burk. ${ }^{16)}$ $K m$ and $V_{\max }$ were calculated from the results.

a slight swelling of the $\alpha_{\mathrm{s} 1}$-casein film on the neutral $\mathrm{pH}$ side. That is, on the alkaline side it will be easier for the entrapped enzyme to come into contact with its substrate, due to spreading of the lattice of the film.

The temperature-activity profiles showed that the thermal stability increased in the high temperature range employed in this immobilization study. This increase in thermal stability was interesting, because the thermal stability of a collagen-enzyme film, the method for which may be similar to our immobilization method, is at least the same as the free enzyme. ${ }^{15)}$ The fact that the enzymes hardly leaked from the support at all shows that this immobilization method involved the tight entrapment of the enzymes into the matrix of the protein film.

The reason why the $K m$ values become greater with this immobilization was thought to be that the substrate affinity for each enzyme decreased, apparently because of the 
lower substrate concentration in the interior of the lattice than that at the exterior. It is interesting that $\beta$-galactosidase with this method showed the reverse as compared with the other enzymes, which indicated a decrease in substrate affinity.

In conclusion, we successfully immobilized some enzymes in the protein film formed by TGase. The type of immobilization might be entrapment in the lattice of the protein film. This immobilization technique, which gave activity yields of 14 to $33 \%$ in the case of $\beta$ galactosidase, was nearly as good as other conventional immobilization methods. Although we obtained good results with the new immobilization technique, many further investigations will be needed before it can be put to practical use.

\section{REFERENCES}

1) K. Mosback, "Methods in Enzymology," Vol. 44, Academic Press Inc., New York, 1976.

2) M. Motoki, H. Aso, K. Seguro and N. Nio, Agric. Biol. Chem., 51, 993 (1987).

3) J. E. Folk and J. S. Finlayson, "Advances in Protein Chemistry," Vol. 1, ed. by C. B. Anfisen, J. T. Edsall and F. M. Richards, Academic Press Inc., New
York, 1977, p.l.

4) N. Nio, M. Motoki and K. Takinami, Agric. Biol. Chem., 49, 2283 (1985).

5) J. H. Connellan, S. I. Chung, N. K. Whetzel, L. M. Bradley and J. E. Folk, J. Biol. Chem., 246, 1093 (1971).

6) M. Motoki and N. Nio, J. Food Sci., 48, 561 (1983); M. Motoki, N. Nio and K. Takinami, Agric. Biol. Chem., 48, 1257 (1984).

7) C. A. Zittle and J. H. Custer, J. Dairy Sci., 46, 1183 (1963).

8) L. Yu-Teh and L. Su-Chen, "Methods in Enzymology," Vol. 28, Academic Press Inc., New York, 1972, p. 702.

9) R. Bentley, "Methods in Enzymology," Vol. 9, Academic Press Inc., New York, 1966, p. 86.

10) U. K. Laemmli, Nature, 227, 680 (1970).

11) L. E. Wierzbicki, V. H. Edwards and F. V. Kosikowski, J. Food Sci., 38, 1070 (1973).

12) K. Omiya, C. Terao, S. Shimizu and T. Kobayashi, Agric. Biol. Chem., 39, 491 (1975).

13) G. O. Hustad, T. Richardson and N. F. Olson, $J$. Dairy Sci., 56, 1111 (1973).

14) F. Morsi, M. Pastore and A. Viglia, J. Dairy Sci., 56, 1123 (1973).

15) F. R. Bernath and W. R. Vieth, "Immobilized Enzymes in Food and Microbial Processes," ed. by A. C. Olson and C. L. Cooney, Plenum Press, New York, 1974, p. 157.

16) H. Lineweaver and D. Burk, J. Am. Chem. Soc., 56, 658 (1934). 